\title{
UNIVERSITYOF
}

FORWARD

THINKING

WESTMINSTER用

WestminsterResearch

http://www.westminster.ac.uk/westminsterresearch

\section{Visualising urban gentrification and displacement in Greater}

London

Zhang, Y., Chapple, K., Cao, M., Dennett, A. and Smith, D.

This is a copy of the accepted author manuscript of the following article: Zhang, Y., Chapple, K., Cao, M., Dennett, A. and Smith, D. (2019) Visualising urban gentrification and displacement in Greater London. Environment and Planning A, Advanced online publication doi:10.1177/0308518X19880211.

The final definitive version is available from the publisher Sage at:

https://dx.doi.org/10.1177/0308518X19880211

(C) The Author(s) 2019

The WestminsterResearch online digital archive at the University of Westminster aims to make the research output of the University available to a wider audience. Copyright and Moral Rights remain with the authors and/or copyright owners. 


\title{
Visualising urban gentrification and displacement in Greater London
}

\author{
Yuerong Zhang, ${ }^{\mathrm{a}, \mathrm{b}}$ Karen Chapple ${ }^{\mathrm{c}}$, Mengqiu Cao ${ }^{\mathrm{a}, \mathrm{d}, *}$, Adam Dennett $^{\mathrm{b}}$, Duncan Smith $^{\mathrm{b}}$ \\ a Bartlett School of Planning, University College London, London, UK \\ ${ }^{\mathrm{b}}$ Centre for Advanced Spatial Analysis, University College London, London, UK \\ ${ }^{\mathrm{c}}$ College of Environmental Design, University of California, Berkeley, Berkeley, USA \\ ${ }^{\mathrm{d}}$ School of Architecture and Cities, University of Westminster, London, UK \\ *Corresponding author: Mengqiu Cao, University of Westminster, 35 Marylebone Road, London, NW1 5LS, \\ UK. Email: m.cao@westminster.ac.uk
}

\begin{abstract}
Gentrification has long been a contentious issue which has prompted debate among scholars, due to variations in its location, timing, context, and types of measurements used. Therefore, it is worth seeking a simple and effective approach to measure the processes of gentrification, which enables comparative studies to be conducted across different cities around the world. Using six sets of thematic data from 2001 and 2011 at the neighbourhood level, this study proposes five types of gentrification and displacement by using Chapple and Zuk's theoretical framework. London was selected as a case study. The results show that gentrification was sweeping in many ways during the 2000s in London, particularly in Inner East London. Some areas in North-west London are identified as vulnerable neighbourhoods at risk of displacement and gentrification. Furthermore, it was found that most of the neighbourhoods experiencing ongoing displacement are concentrated in Outer London and Inner South London. The typology provides a useful starting point for planners and policymakers to gain deeper insights into the progress of gentrification in London. Additionally, this work can serve as an example to illustrate the potential for using similar types of open source code and census data to estimate the degree of gentrification in other cities.
\end{abstract}

\section{Key words}

Gentrification, displacement, socio-spatial inequality, London 
Gentrification refers to the process whereby, through an influx of capital and higherincome, higher-educated residents transforms a low-income neighbourhood (Chapple and Loukaitou-Sideris, 2019). It is not only a spatial manifestation of socio-economic inequalities, but also acts to exacerbate socio-spatial divisions via the displacement of existing residents (Hochstenbach and Musterd, 2018). Therefore, identifying the progress of gentrification is of great importance, particularly for cities seeking to cope with rapidly growing polarisation. The increasing availability of open data sources enables the discovery of the landscapes of gentrification, while the development of open source code enables replication by planners, researchers and policymakers (Reades, Souza and Hubbard, 2019). This then makes it possible to carry out a comparative analysis between different cities or conduct longitudinal evaluations to delineate the gentrification trajectories within one city. Accordingly, the main aim of this article is to take Greater London as an example to illustrate the potential for using open data and open source code (see Author's note) in order to produce a general picture of the gentrification typologies at neighbourhood level (Lower Super Output Areas (LSOA)).

This analysis used data obtained from: 1) the Office for National Statistics (ONS); 2) the Greater London Authority (GLA); and 3) the Land Registry. Following Chapple and Zuk's (2016) analytical framework, we firstly visualised six key thematic maps to depict gentrification related landscapes in 2011. Figure 1 reveals that, the percentage of non-white residents, and the percentage of people with a higher-education follow a similar pattern to that of household income, i.e., the lower-income households are located in the Eastern and NorthWestern regions of suburban London.

We combine six indicators to produce a typology of gentrification and displacement in Greater London (see the appendix for further details). Figure 2 displays the five types of neighbourhoods in the typology: 1) those that are not losing low-income households; 2) those at risk of gentrification; 3) neighbourhoods experiencing ongoing displacement; 4) neighbourhoods experiencing ongoing gentrification, and 5) those containing mainly moderate- to high-income households. Overall, gentrification has had far-reaching effects during the 2000s in London. The neighbourhoods experiencing ongoing gentrification are mostly located in Inner London and are distributed across traditionally working-class areas of East London (Freenman, Cassola and Cai, 2016) (e.g. Barking and Dagenham, and the Olympic development area in Hackney). The neighbourhoods experiencing ongoing displacement are mainly located in Outer London and Inner South London, particularly in the Lambeth and Lewisham areas, accounting for $2.91 \%$ of Londoners in total. However, we cannot presume that this is gentrification-induced displacement. These areas experienced a significant loss of low-income households while showing few signs of gentrification occurring between 2001 and 2011. Swathes of neighbourhoods in North-western areas (e.g. Brent, Ealing and Barnet) of London are identified as being at risk of gentrification. Meanwhile, 129 neighbourhoods, accounting for nearly $2.8 \%$ of Londoners, are particularly vulnerable to displacement and gentrification. The typology map can further enhance our understanding of the patterns of neighbourhood change in addition to potentially helping to predict future trends.

Although this work can neither specify the precise magnitude of gentrification nor uncover the mechanism (or causality) of gentrification, it attempts to develop a replicable typology of gentrification and displacement that can serve as the basis for direct comparison across U.K. cities, as well as other cities around the world with similar census variable availability. Further research could use similar data and codes to replicate the London case in other cities in order to estimate the degree of gentrification using the same comparative basis. 


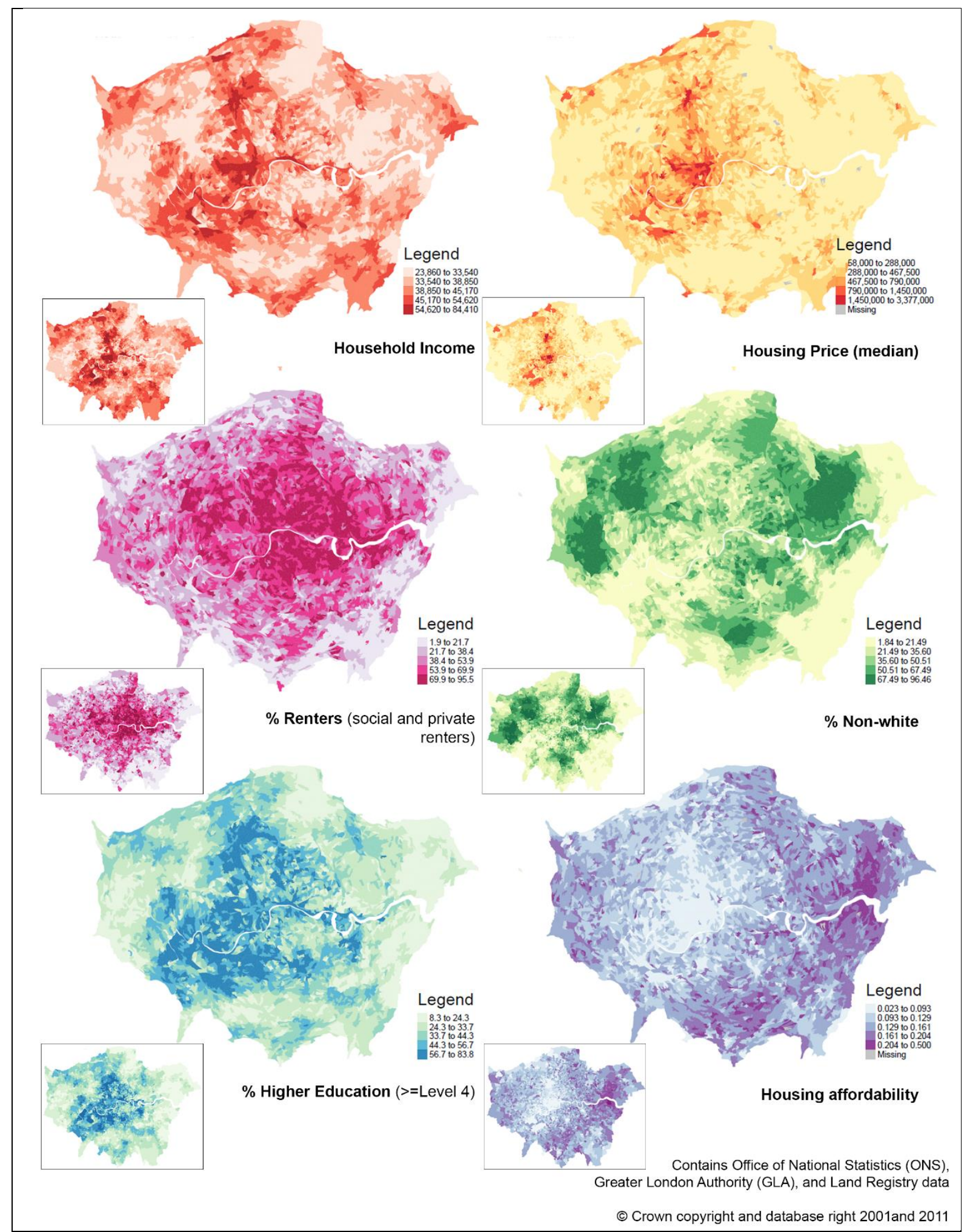

Figure 1. Cartogram of key themes related to gentrification by populations in Greater London in 2011 (the distortion is based on residential population in 2011). The original maps are provided at the bottomleft of each of the embedded six diagrams for comparison. 


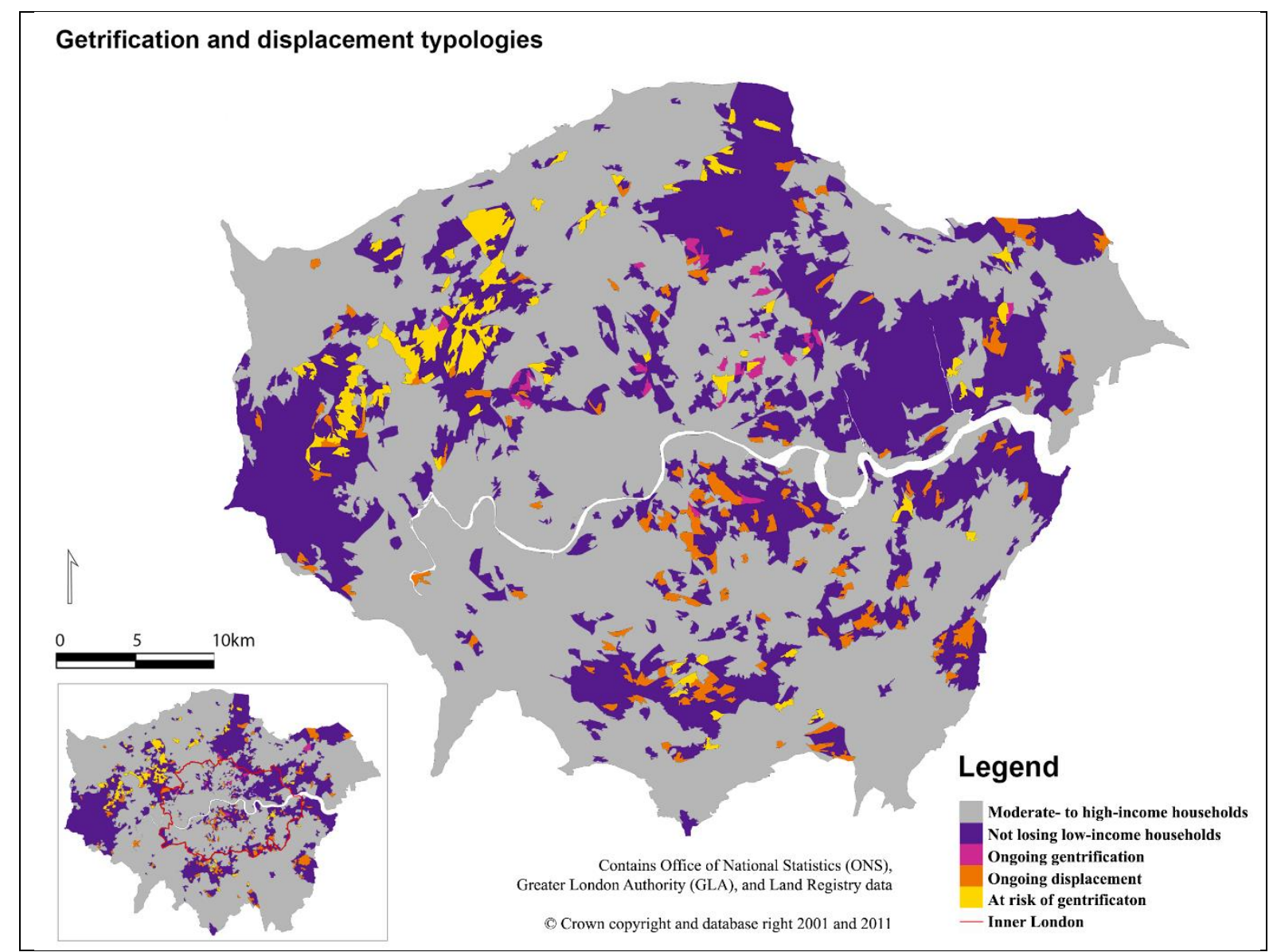

Figure 2. Gentrification and displacement typologies for Greater London in 2011 at neighbourhood level (the distortion is based on residential population in 2011). The original map is provided at the bottom-left of the diagram for comparison. 


\section{Author's note}

Software: These visualisations were produced using the graphics packages tmap, rgdal, tmaptools andcartogram within the $\mathrm{R}$ Studio programming language. The code available to reproduce these figures isavailable from the following url: https://github.com/YuerongZhang/Gentrification_London/blob/master/coding_london_grnti. $\mathrm{R}$

Data details can be found at: https://github.com/YuerongZhang/Gentrification_London/blob/master/README.md

\section{Declaration of conflicting interests}

The author(s) declared no potential conflicts of interest with respect to the research, authorship, and/or publication of this article.

\section{ORCID iD}

Mengqiu Cao $\quad$ https://orcid.org/0000-0001-8670-4735

Adam Dennett $\quad$ https://orcid.org/0000-0001-8036-0185

\section{References}

Chapple K, and Loukaitou-Sideris A (2019) Transit-Oriented Displacement or Community Dividends? Understanding the Effects of Smarter Growth on Communities. Cambridge, MA: MIT Press.

Chapple K, and Zuk M (2016) Forewarned: The use of neighborhood early warning systems for gentrification and displacement. Cityscape, 18(3): 109-130.

Freeman L, Cassola A and Cai T (2016) Displacement and gentrification in England and Wales: A quasi-experimental approach. Urban Studies, 53(13): 2797-2814.

Hochstenbach C, and Musterd S (2018) Gentrification and the suburbanization of poverty: Changing urban geographies through boom and bust periods. Urban Geography, 39(1): 2653.

Reades J, De Souza J and Hubbard P (2019) Understanding urban gentrification through machine learning. Urban Studies, 56(5): 922-942. 


\section{Appendix}

Gentrification and Displacement Census Typologies

\begin{tabular}{|l|l|}
\hline Typology & Typology criteria \\
\hline Not losing low-income households & $\begin{array}{l}\text { Low income group in 2011 (see definition in note1) } \\
\text { Not classified as at risk of gentrification or ongoing gentrification } \\
\text { or displacement. }\end{array}$ \\
\hline At risk of gentrification & $\begin{array}{l}\text { Low income group in 2011 } \\
\text { Vulnerable in 2011 (see note 2) } \\
\text { 'Hot market' from 2001 to 2011 (see note 3) } \\
\text { Not currently undergoing displacement or ongoing gentrification }\end{array}$ \\
\hline Ongoing displacement & $\begin{array}{l}\text { Low income group in 2011 } \\
\text { Loss of low-income households from 2001 to 2011 } \\
\text { Few signs of gentrification }\end{array}$ \\
\hline Ongoing gentrification & $\begin{array}{l}\text { Low income group in 2011 } \\
\text { Gentrified between 2001-2011 (defined in note 4) }\end{array}$ \\
\hline Moderate- to high-income households & Groups that are not recognised as low-income groups \\
\hline
\end{tabular}

\section{Note:}

1. Low income group in 2011

If the median household income is lower or equal to $95 \%$ of the median household income in 2011, then it will be identified as a low-income group. Conversely, if the median household income is higher than $95 \%$ of the median household income, then it will be identified as a moderate-to high-income group. In the case of London, 3025 LSOAs are identified as containing mostly moderate- to high-income households, and 1810 LSOAs are identified as containing predominantly low-income households.

For example, there are two official ways of defining low-income groups in the UK. The first one defines households classed as being low income if they live on less than $60 \%$ of the UK's median income (https://www.ethnicity-facts-figures.service.gov.uk/work-pay-and-benefits/pay-and-income/low-income/latest).

As the data is at aggregated level, if we apply this criterion to select the low-income neighbourhoods, none of the LSOAs are identified as low-income. The second definition is from the Greater London Authority (http://content.tfl.gov.uk/people-on-low-incomes-summary.pdf). It states that $41 \%$ of Londoners can be classed as having a low annual household income. We have tried a different ratio and found $95 \%$ of the median household income to be a suitable benchmark for differentiating the low-income groups and moderate- to high-income groups.

2. Vulnerable in 2011

Housing affordability indicates if housing prices are increasing at a lower rate than the median speed and any 2 of the following 3 :

- $\%$ higher education $<$ London median

- $\%$ renters $>$ London median

- $\%$ non-white $>$ London median

3. "Hot market" from 2001 to 2011

Change in median real rent (social and private) $>$ London median

4. Gentrification from 2001 to 2011

Vulnerable in 2001

"Hot market"

Demographic change

- Difference in \% higher education $>$ London median

- Difference in \% median household income > London median 